\title{
Pulsatile secretion of LH during the periovulatory and luteal phases of the oestrous cycle in the Père David's deer hind (Elaphurus davidianus)
}

\author{
A. S. I. Loudon, B. J. McLeod* and J. D. Curlewis $\dagger$ \\ $M R C / A F R C$ Comparative Physiology Research Group, Institute of Zoology, Regent's Park, \\ London, NWI 4RY, UK; and *Cattle and Sheep Production Department, AFRC Institute \\ for Grassland and Animal Production, Hurley Research Station, Hurley, Maidenhead, \\ Berks SL6 5LR, UK
}

\begin{abstract}
Summary. Changes in the secretion of LH during the oestrous cycle were studied in 5 tame Père David's deer in which ovulation was synchronized with progesterone implants and prostaglandin injections. Plasma LH concentrations were measured in samples collected at 15 -min intervals for a 36 -h period, starting $16 \mathrm{~h}$ after the removal of the progesterone implants (follicular phase), and for a further 10 -h period 10 days after the removal of the progesterone implants (luteal phase). In all animals, there was a preovulatory surge of $\mathrm{LH}$ and behavioural oestrus which occurred at a mean time of $59.6 \mathrm{~h}( \pm 3.25)$ and $69 \mathrm{~h}$ respectively following implant removal. LH pulse frequency was significantly higher during the follicular phase $(0.59 \pm 0.03$ pulses/h) than the luteal phase $(0.24 \pm 0.2$ pulses/h), thus confirming in deer findings from research on domesticated ruminants. There were no significant differences between the follicular and luteal phases in mean plasma LH concentrations $(0.57 \pm 0.09$ and $0.74 \pm 0.13 \mathrm{ng} /$ $\mathrm{ml})$ or mean pulse amplitude $(0.99 \pm 0.14$ and $1.05 \pm 0.21 \mathrm{ng} / \mathrm{ml})$ for the follicular and luteal phase respectively. The long interval from the removal of progesterone to the onset of the LH surge and the absence of a significant difference in mean LH concentration or pulse amplitude in the follicular and luteal phases resemble published data for cattle but differ from sheep in which there is a short interval from luteal regression to the onset of the surge and a marked increase in LH pulse amplitude during the luteal phase.
\end{abstract}

Keywords: deer; LH; oestrous cycle; pulsatile secretion

\section{Introduction}

Changes in the secretion of pituitary and ovarian hormones during the oestrous cycle have been described for a number of domesticated ruminant species including the cow (Walters \& Schallenberger, 1984), goat (BonDurant et al., 1981; Mori \& Kano, 1984) and the ewe (Foster et al., 1975; Yuthasastrakosol et al., 1977; Baird, 1978). In these species, there is a significant increase in the pulsatile secretion of $\mathrm{LH}$ following regression of the corpus luteum which in turn elicits a sustained rise in plasma oestrogen concentrations (Karsch et al., 1979; Schallenberger et al., 1984). Temporal changes in tonic levels of LH during the oestrous cycle have been described for deer (roe deer: Schams et al., 1980; white-tailed deer: Plotka et al., 1980; fallow deer: Asher et al., 1986) but blood samples were collected infrequently in these studies and so it was not possible to monitor

tPresent address: Department of Physiology and Pharmacology, University of Queensland, St Lucia, Brisbane, Queensland 4072, Australia. 
episodic LH secretion. In addition, animals were often restrained in crushes and it has been suggested that the stress encountered during these sampling procedures may influence the secretion of LH in deer (Asher et al., 1986). To date, there have been no data published on the changes in the pattern of pulsatile secretion of LH during the oestrous cycle in any species of deer. The objective of the present study was to characterize pulsatile secretion of $\mathrm{LH}$ during both the follicular phase and luteal phase in a group of tame Père David's deer which had been hand-reared and did not require restraint in order to collect samples. Information on the temporal pattern of $\mathrm{LH}$ secretion in naturally cycling deer would be invaluable in attempts to improve fertility in farmed or endangered species of deer.

\section{Materials and Methods}

\section{Animals and management}

Five tame adult post-pubertal (four 2-year-olds and one 3-year-old; mean liveweight $162 \pm 6.3 \mathrm{~kg}$ ) female Père David's deer (Elaphurus davidianus) were monitored in early-mid-breeding season (early September). The onset of the breeding season had been determined from progesterone determinations, and profiles from these animals have been previously described (Curlewis et al., 1988). The animals were maintained on pasture, except during the intensive blood-sampling periods when they were housed indoors, under conditions of natural photoperiod and temperature, and were fed hay and pelleted lucerne.

Treatment and blood sampling. To synchronize oestrus, all animals were pretreated with progesterone administered via subcutaneous implants (Sil-Estrus, Ceva Ltd, Sydney, Australia) which contained $375 \mathrm{mg}$ progesterone in a silicone-elastomer matrix. Each animal received 5 implants (inserted in the axillary region under local anaesthetic), a dose which has previously been shown to elevate plasma progesterone concentrations to mid-luteal phase values (in excess of $3.0 \mathrm{ng} / \mathrm{ml}$; Curlewis et al., 1988). The implants were inserted on 28 August and removed 11 days later (8 September; Day 0). At the time of implant removal, each animal was treated with prostaglandin (l ml Estrumate; Coopers Animal Health, Crewe, Cheshire, UK) and was fitted with an indwelling jugular catheter. At the time of implant insertion and removal, animals were sedated with $20 \mathrm{mg}$ xylazine (Bayer Pharmaceuticals, Leverkusen, W. Germany). Blood samples for $\mathrm{LH}$ determination were collected at $15-$ min intervals for $36 \mathrm{~h}$, starting $16 \mathrm{~h}$ after implant removal. Thereafter, samples were collected at 3-h intervals for a further $48 \mathrm{~h}$. A second period ( $10 \mathrm{~h})$ of blood sampling at 15-min intervals was undertaken 9 days after implant removal to assess luteal-phase patterns of LH secretion. Blood samples for progesterone analysis were collected 3 times weekly by venepuncture for a 6-week period, starting 8 days before the withdrawal of the progesterone implants. In addition, blood samples were taken daily for the first 10 days following implant removal.

Detection of oestrus. Animals were checked twice daily (at 08:00 and 17:00 h) from Days 1 to 5 after progesterone implant removal for signs of behavioural oestrus. Overt oestrus was scored on an arbitrary 3-point scale (from 1, no signs of oestrus, to 3, full overt oestrus). When in oestrus, these deer will actively seek human contact and rub their head against the observer. When pressure is applied to the hind-quarters of the animal, it will remain stationary rather than move off quickly as would occur in a non-oestrous animal. During the experimental period, behavioural observations were made twice daily. All checks for oestrous behaviour were undertaken by the same person, who was also responsible for the routine day-to-day care of the animals.

\section{Hormone assays}

Luteinizing hormone. Plasma LH ccncentrations were measured using the heterologous ovine double-antibody radioimmunoassay of Foster \& Crighton (1974), with the modifications described by McLeod et al. (1982). Binding inhibition curves of serial dilutions of deer plasma ran parallel with that of the ovine standard preparation (see Fig. 1). Within this study, the limit of sensitivity of the assay was $0.2 \mathrm{ng} \mathrm{NIH-LH}-24$ equivalents $/ \mathrm{ml}$ plasma and the intra-and inter-assay coefficients of variation were 8.6 and $9.8 \%$ respectively. Physiological validation of the assay in this species was tested by determining the $\mathrm{LH}$ response to 2 doses of exogenous GnRH $(0.5$ and $10 \mu \mathrm{g})$ administered by i.v. injection during mid-anoestrus (see Fig. 2).

Progesterone. Plasma samples were extracted using diethyl ether and progesterone concentrations measured by a radioimmunoassay method previously validated for use in this species (Curlewis et al., 1988). The inter- and intraassay coefficients of variation were $4.6 \%$ and $10.5 \%$ respectively and the buffer blank was below the limit of detection of the assay $(0 \cdot 08 \mathrm{ng} / \mathrm{ml})$. 


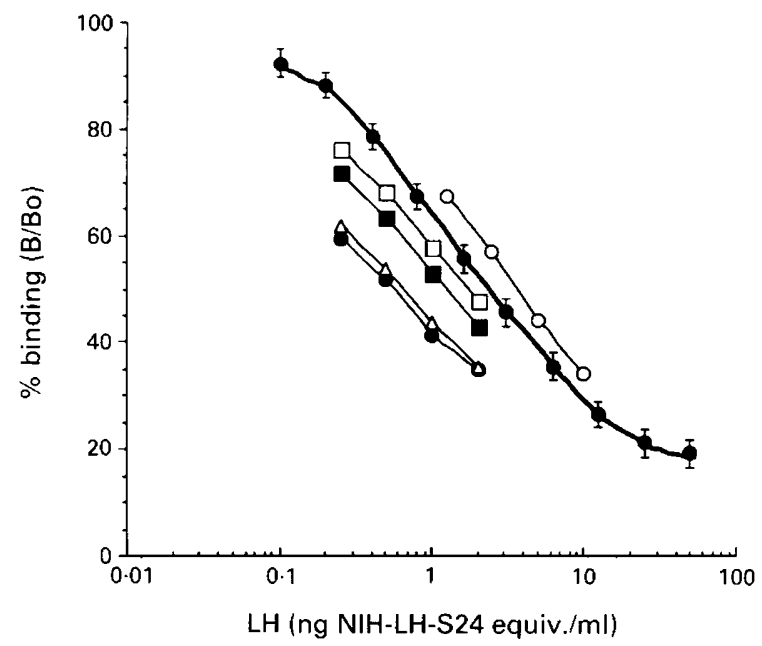

Fig. 1. Binding inhibition curves for an ovine LH standard ( $-\longrightarrow$, NIH-LH-S24) for 4 deer plasmas $(\triangle \longrightarrow \triangle, \mathrm{Y} 12 ;-\bigcirc, \mathrm{Y} 1 ; \mathrm{O}-\mathrm{O}, \mathrm{B} 56 ; \mathbf{\square}-\mathbf{\square}, \mathrm{B} 63)$ and for sheep plasma $(\square-\square$, SP4).

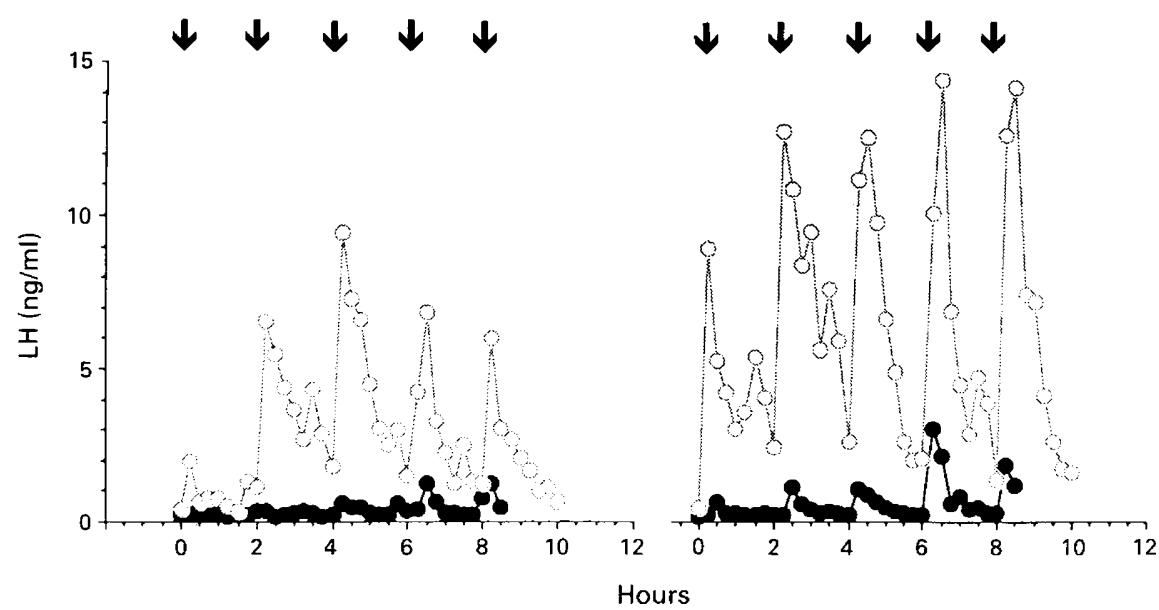

Fig. 2. Plasma LH concentrations in 2 Père David's deer hinds in response to 5 injections of $0.5 \mu \mathrm{g}(-10)$ and $10.0 \mu \mathrm{g}(\mathrm{O}-\mathrm{O}) \mathrm{GnRH}$, given at 2-h intervals. The time of $\mathrm{GnRH}$ injections is shown by the arrows. Blood samples were taken at $15-\mathrm{min}$ intervals.

\section{Analysis of data}

An LH episode was defined as (1) an increase in plasma LH concentrations of at least 4 times the coefficient of variation of 100 randomly selected duplicate pairs, in which (2) there was not more than one sample point between the preceding trough and peak and (3) there were no less than 2 sample points between the peak and the succeeding trough. The definition used to characterize the preovulatory surge was that of McLeod et al. (1985), namely that there was a sustained $(>5 \mathrm{~h}$ ) elevation in LH concentrations above $4 \mathrm{ng} / \mathrm{ml}$ and that the peak concentration during this time exceeding $10 \mathrm{ng} / \mathrm{ml}$. The onset of the peak was defined as the time when the concentration first exceeded $4 \mathrm{ng} / \mathrm{ml}$. Differences in mean LH value and episode amplitude during the follicular and luteal phases were assessed by unpaired $t$ test; comparison with time across the follicular phase were undertaken by ANOVA with repeated measures. Subsequently, comparisons of mean $\mathrm{LH}$ concentrations at different stages of the follicular phase were undertaken by paired $t$ test. All results are expressed as mean \pm s.e.m. 


\section{Results}

\section{Oestrous behaviour}

Of the 5 animals, 4 were observed to be exhibiting full standing oestrus when checked at $08: 00 \mathrm{~h}$ on Day $3(64.3 \pm 0.48 \mathrm{~h}$ after implant removal). These animals remained in oestrus throughout the day and were given an oestrous score of 2 the following morning. The remaining animal (B74) was in full standing oestrus at $08: 00 \mathrm{~h}$ of the 4 th day ( $88 \mathrm{~h}$ after implant removal), and had an oestrous score of 2 when checked at 17:00 h the same day. Four of the 5 animals were observed to return to oestrus on Days 21 or 22 after implant removal but the remaining animal (B74) was not observed to return to oestrus.

\section{Plasma progesterone concentrations}

Mean plasma progesterone concentrations were $5.6( \pm 0.5) \mathrm{ng} / \mathrm{ml}$ while the implants were in situ. In the blood samples taken $16 \mathrm{~h}$ after implant removal mean concentrations were still significantly elevated $(0.7 \pm 0.1 \mathrm{ng} / \mathrm{ml})$ but by Day 2 they had fallen to basal levels $(<0.2 \mathrm{ng} / \mathrm{ml})$. By the 4 th day after oestrus, progesterone concentrations increased significantly in all animals $(P<0 \cdot 05$, and later reached a mean maximum luteal-phase concentration of $3 \cdot 6( \pm 0 \cdot 1) \mathrm{ng} / \mathrm{ml}$. In 4 animals, progesterone concentrations fell between Days 18 and 21 after the synchronized oestrus; in the remaining animal (B74) they remained elevated for a further 11 days and declined on Day 32.

Plasma progesterone concentrations were also measured in blood samples collected at 3-h intervals from Days 1 to 4 after implant removal. Mean progesterone concentrations for 4 animals did not increase over this period (range of values $0.15-0.7 \mathrm{ng} / \mathrm{ml}$ ), but in the remaining animal (B74) there was a transient increase in progesterone concentrations to a peak of $1 \cdot 1 \mathrm{ng} / \mathrm{ml}$ over a 9-h period starting $15 \mathrm{~h}$ after the onset of the LH surge.

\section{Plasma LH concentrations}

Assessment of episodic patterns of LH secretion during the follicular phase of the oestrous cycle was restricted to 4 animals due to the failure of the indwelling catheter in the remaining deer (B74). This animal was blood sampled at 3 -h intervals for a $30-\mathrm{h}$ period starting $63 \mathrm{~h}$ after progesterone implant removal in order to monitor the preovulatory LH surge. Characteristics of LH secretion are summarized in Table 1.

Table 1. Mean LH concentrations and LH episode patterns during the follicular and luteal phases of the oestrous cycle in Père David's deer

\begin{tabular}{lccccccc}
\hline & \multicolumn{3}{c}{ Follicular phase } & & \multicolumn{3}{c}{ Luteal phase } \\
\cline { 2 - 3 } Deer & $\begin{array}{c}\text { Mean } \\
\text { LH conc. } \\
(\mathrm{ng} / \mathrm{ml})\end{array}$ & $\begin{array}{c}\text { Episode } \\
\text { frequency } \\
(\mathrm{no} . / \mathrm{h})\end{array}$ & $\begin{array}{c}\text { Episode } \\
\text { amplitude } \\
(\mathrm{ng} / \mathrm{ml})\end{array}$ & & $\begin{array}{c}\text { Mean } \\
\text { LH conc. } \\
(\mathrm{ng} / \mathrm{ml})\end{array}$ & $\begin{array}{c}\text { Episode } \\
\text { frequency } \\
(\text { no./h) }\end{array}$ & $\begin{array}{c}\text { Episode } \\
\text { amplitude } \\
(\mathrm{ng} / \mathrm{ml})\end{array}$ \\
\hline B56 & 0.60 & 0.56 & 0.92 & & 0.57 & 0.3 & 0.80 \\
B58 & 0.48 & 0.53 & 1.13 & & 1.16 & 0.2 & 1.79 \\
B62 & 0.80 & 0.67 & 1.27 & & 0.46 & 0.2 & 0.57 \\
B74 & - & - & - & & 0.89 & 0.3 & 1.19 \\
Y12 & 0.40 & 0.58 & 0.63 & & 0.63 & 0.2 & 0.88 \\
Mean & 0.57 & 0.59 & 0.99 & & 0.74 & 0.24 & 1.05 \\
s.e.m. & \pm 0.09 & \pm 0.03 & \pm 0.14 & & \pm 0.13 & \pm 0.02 & \pm 0.21 \\
\hline
\end{tabular}


The mean $\mathrm{LH}$ concentration recorded during the follicular phase $(0.57 \pm 0.09 \mathrm{ng} / \mathrm{ml})$ was not significantly different from that in the luteal phase $(0.74 \pm 0.13 \mathrm{ng} / \mathrm{ml})$. $\mathrm{LH}$ episodes were recorded in all animals during each of the profile bleeds, but these occurred at a significantly $(P<0.001)$ higher frequency during the follicular phase $(0.59 \pm 0.03$ and $0.24 \pm 0.02$ pulses/h for the follicular and luteal phases respectively; see Fig. 3, Table 1). There was no significant difference in the mean amplitude of $\mathrm{LH}$ episodes recorded during the follicular and luteal phases $(0.99 \pm 0 \cdot 14$ and $1.05 \pm 0.21$, respectively). The preovulatory $\mathrm{LH}$ surge was recorded in all 5 deer. The surge occurred at $59.4 \pm 3.3 \mathrm{~h}$ after removal of the progesterone implants, had a mean duration of $15.3 \pm 1.2 \mathrm{~h}$ and reached a mean maximum concentration of $17.09 \pm 2.85 \mathrm{ng} / \mathrm{ml}$ (see Fig. 4). In each of the animals, the onset of behavioural oestrus occurred within $9 \mathrm{~h}$ after the onset of the $\mathrm{LH}$ surge at a mean time of $69.09 \pm 4.79 \mathrm{~h}$ after implant removal.
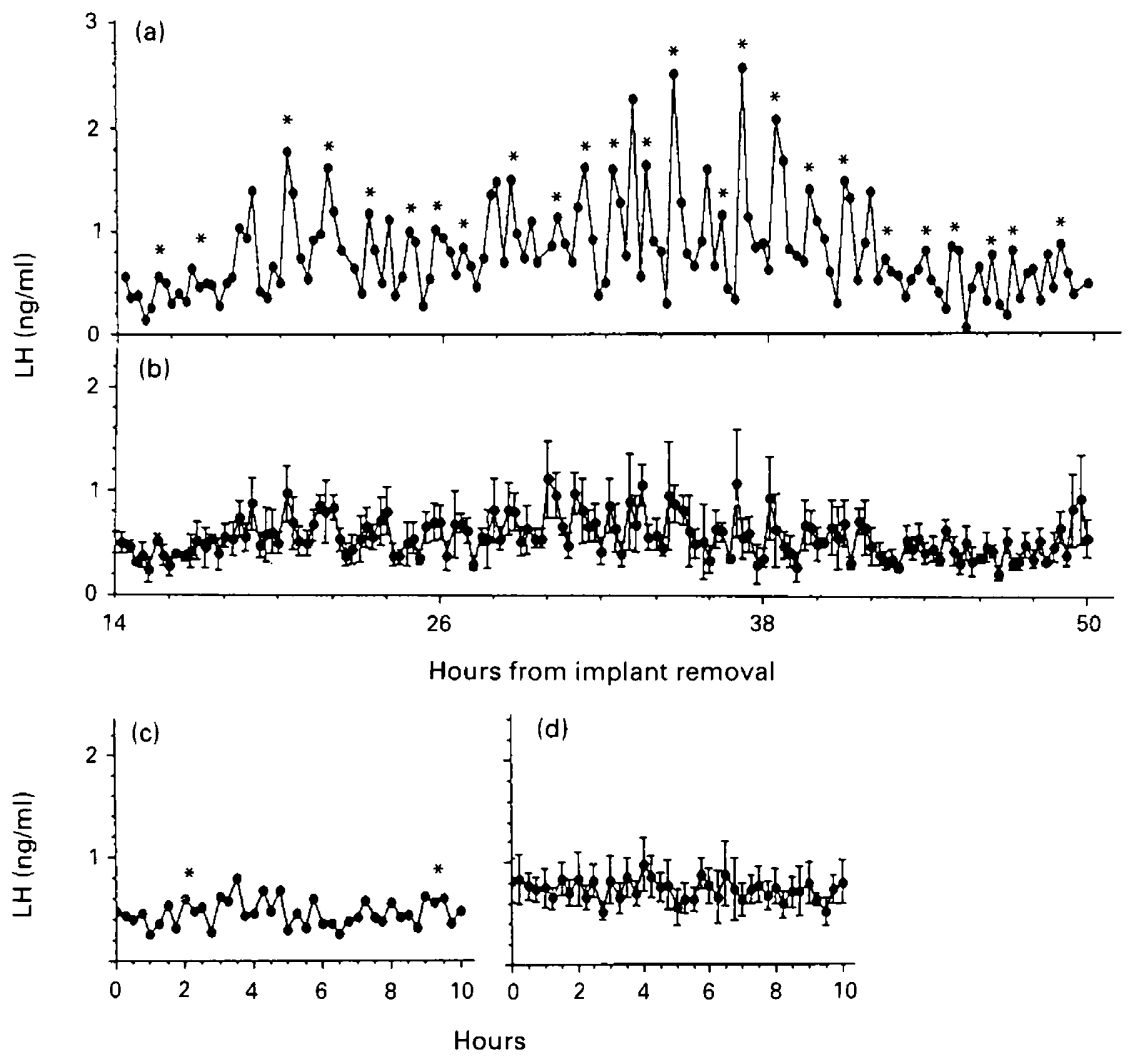

Fig. 3. Plasma LH concentrations in an individual deer (B62) during the follicular phase (a) and luteal phase (c). (b) Mean plasma LH concentrations in 4 Père David's deer hinds synchronized by removal of progesterone implants $( \pm$ s.e.m.) over a 36 -h period in the follicular phase $(\mathrm{N}=$ 4) and (d), in the same animals over a 10 -h period during the luteal phase $(\mathrm{N}=5)$. Blood samples were taken at $15 \mathrm{~min}$ intervals.

A comparison of mean $\mathrm{LH}$ concentrations between 6-h periods during the follicular phase indicated that there were significant changes in mean LH over the $36-\mathrm{h}$ period preceding the preovulatory surge, with an elevation in mean plasma concentration during the middle of the $36 \mathrm{~h}$ profile. Mean LH concentrations were $0.42 \pm 0.04,0.53 \pm 0.04,0.88 \pm 0.09,0.80 \pm 0.05$, $0.73 \pm 0.04$ and $0.48 \pm 0.05$ for the $6 \times 6$-h periods from the onset of the LH surge, i.e. surge to $-6,-6$ to $-12,-12$ to $-18,-18$ to $-24,-24$ to -30 and -30 to $-36 \mathrm{~h}$ respectively before 


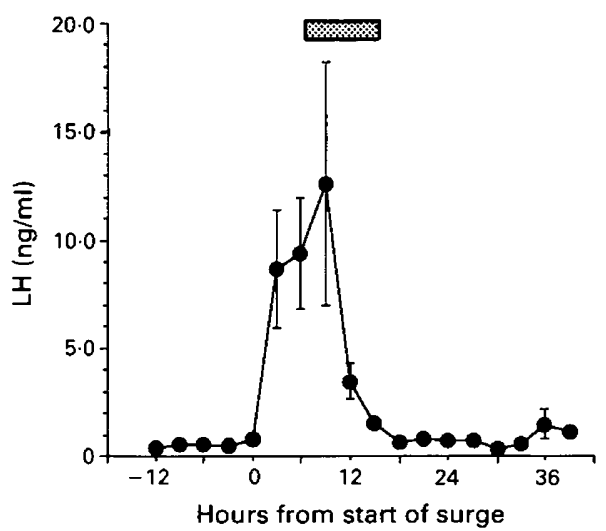

Fig. 4. Mean ( \pm s.e.m.) plasma LH concentrations in Père David's deer hinds $(N=5)$ after withdrawal of progesterone implants. The profiles have been standardized about the onset of the preovulatory LH surge. The period over which the animals displayed behavioural oestrus is shown by the hatched bar. Blood samples were taken at 3-h intervals.

the onset of the surge. There was a significant effect of time on mean LH values (ANOVA) across the follicular phase. Subsequent pairwise $t$ tests indicated significant differences when either the first or last 6-h period was compared with the 2 periods -12 to -18 and -18 to $-24 \mathrm{~h}$ before the onset of the LH surge $(P<0.001)$.

\section{Discussion}

The results reported here present the first data on the pulsatile pattern of $\mathrm{LH}$ secretion during the oestrous cycle in any species of deer. The mean LH pulse frequency during the follicular phase $(0.58$ pulses $/ \mathrm{h})$ is similar to that reported for cattle (Page et al., 1987; $0.57 \mathrm{pulses} / \mathrm{h}$ ) and sheep (Yuthasastrakosal et al., 1977;0.68 pulses/h). However, while peak LH surge values are similar to those reported for cattle (range 17-34 ng/ml; Rahe et al., 1980; Peters, 1984; Walters \& Schallenberger, 1984) they are 3-6 times lower than those reported for sheep (Baird \& Scaramuzzi, 1976; McLeod \& Haresign, 1984; McLeod et al., 1982) or goats (BonDurant et al., 1981). The duration of the LH surge in Père David's deer is similar to that reported for fallow deer (Asher et al., 1986) and sheep (McLeod et al., 1982, 1983; McLeod \& Haresign, 1984) but approximately double that reported for cattle (Rahe et al., 1980; Peters, 1984; Walters \& Schallenberger, 1984) or goats (BonDurant et al., 1981). The decline in mean LH concentrations over the 18-24-h period before the onset of the LH surge is similar to the events which occur during the oestrous cycle of domestic ruminants (sheep: McLeod et al., 1988; cattle: Walters \& Schallenberger, 1984) and may be attributable to the effects of increased oestrogen secretion, which is known to reduce LH pulse amplitude at high concentrations (Kesner et al., 1981).

Our observations in the Père David's deer that there are no significant differences in either the mean LH concentrations and mean pulse amplitude between the follicular and the luteal phase are broadly in accord with studies in cattle (Page et al., 1987). However, in the ewe there is a dramatic increase in amplitude of LH pulses during the luteal phase (Karsch et al., 1979; Goodman \& Karsch, 1980, 1981). Our results differ from those for ewes since LH pulse amplitude was not significantly increased during the luteal phase. It is possible, however, that high-amplitude LH pulses do occur in deer but at such low frequency that they may not be detected within a 10-h sampling period.

In many studies of domesticated ruminants significant reductions in $\mathbf{L H}$ pulse frequency during the luteal phase of the oestrous cycle have been reported (Page et al., 1987; Walters \& 
Schallenberger, 1984; Walters et al., 1984) while steroid hormone replacement studies with the ovariectomized ewe in the breeding season have indicated that progesterone significantly reduces LH pulse frequency (Goodman \& Karsch, 1980; Whisnant \& Goodman, 1988). It is now generally accepted that in ruminants the reduction in pulse frequency in the luteal phase is a consequence of the synergistic interaction of follicular oestradiol and luteal progesterone (Karsch et al., 1980; Martin, 1984). Our observations of a reduction in pulse frequency during the luteal phase suggest that a similar mechanism operates in deer.

Several authors have reported a significant elevation in progesterone concentrations at the time of the LH surge in domesticated ruminants when blood samples were collected from the ovarian vein or vena cava (Wheeler et al., 1975; Walters \& Schallenberger, 1984). In addition, Asher et al. (1986) have reported that a similar elevation occurred in progesterone in jugular blood samples at the time of the LH surge in some but not all fallow deer. In this study, we observed a transient rise in progesterone concentrations in jugular samples at the time of the LH surge in $1 / 5$ animals and its duration was similar to that observed by Asher et al. (1986) in fallow deer.

There are comparatively few data on the time of onset of behavioural oestrus in deer in relation to luteal regression. Curlewis et al. (1988) reported that the onset of behavioural oestrus in Père David's deer hinds occurred $71 \mathrm{~h}$ after progesterone implant removal and prostaglandin injection. However, Curlewis et al. (1988) also showed that oestrus occurred approximately $29 \mathrm{~h}$ earlier in Père David's deer synchronized with intravaginal sponges containing a progesterone analogue. In fallow deer, oestrus (as detected by a vasectomized buck) occurs $48-56 \mathrm{~h}$ following removal of an intravaginal progesterone-containing device (Asher et al., 1986), times broadly in accord with an interval of $59 \mathrm{~h}$ from prostaglandin treatment to onset of oestrus in cattle (Walters \& Schallenberger, 1984), but later than the 36-48-h intervals reported for synchronized sheep (Wallace \& McNeilly, 1985; Wallace et al., 1988). It is possible that in deer the time of oestrus, and therefore the time taken to complete preovulatory follicular development, may resemble that in cattle rather than sheep. In the present study behavioural oestrus occurred approximately $9 \mathrm{~h}$ after the onset of the LH surge in all 5 animals but these data were not based on a continuous monitoring for oestrous behaviour. It is therefore possible that more frequent monitoring would have demonstrated a much closer synchrony between onset of oestrus and the LH surge. In a study of the fallow deer, Asher et al. (1986) reported a close synchrony between the LH surge and behavioural oestrus (based on a more frequent monitoring of animals than in the current study) and in this respect fallow and Père David's deer appear to be similar to domesticated animals such as goats (BonDurant et al., 1981) and sheep (McLeod \& Haresign, 1984).

In summary, characteristics of the secretion of LH during the oestrous cycle in deer are similar to those of domesticated ruminants. We did not observe, however, any increase in LH pulse amplitude during the luteal phase. The relative degree of synchrony between the animals studied with respect to the timing of the onset of the $\mathrm{LH}$ surge and the close synchrony with the onset of behavioural oestrus means that artificial manipulations of fertility in deer, including AI or induction of ovulation with exogenous $\mathrm{GnRH}$, may become routine technical procedures.

We thank Alison Beasey and B. Eves for their care and husbandry of the animals and Liang Yingnan for assistance with the collection of blood samples; and Anne Coleman and Jeni Boyle for assistance with hormone analysis.

\section{References}

Asher, G.W., Barrell, G.K. \& Peterson, A.J. (1986) Hormonal changes around oestrus in farmed fallow deer, Dama dama. J. Reprod. Fert. 78, 487-496.

Baird, D.T. (1978) Pulsatile secretion of LH and ovarian estradiol during the follicular phase of the sheep estrous cycle. Biol. Reprod. 18, 359-364.
Baird, D.T. \& Scaramuzzi, R.J. (1976) Changes in the secretion of ovarian steroids and pituitary luteinizing hormone in the periovulatory period in the ewe: the effect of progesterone. J. Reprod. Fert. 70, 237-245.

BonDurant, R.H., Darien, B.J., Munro, C.J., Stabenfeldt, G.H. \& Wang, P. (1981) Photoperiod induction of 
fertile oestrus and changes in $\mathrm{LH}$ and progesterone in yearling dairy goats (Capra hircus). J. Reprod. Fert. 63, $1-9$.

Curlewis, J.D., Loudon, A.S.I. \& Coleman, A.P.M. (1988) Oestrous cycles and the breeding season of the Père David's deer hind (Elaphurus davidianus). $J$. Reprod. Fert. 82, 119-126.

Foster, J.P. \& Crighton, D.B. (1974) Luteinizing hormone (LH) release after single injections of synthetic $\mathrm{LH}$ releasing hormone ( $\mathrm{LH}-\mathrm{RH})$ in the ewe at three different reproductive stages and comparison with natural $\mathrm{LH}$ release at oestrus. Theriogenology 2, 87-100.

Foster, D.L., Lemons, J.A., Jaffe, R.B. \& Niswender, G.D. (1975) Sequential patterns of circulating luteinizing hormone and follicle stimulating hormone in female sheep from early post-natal life through to the first estrous cycle. Endocrinology 97, 985-994.

Goodman, R.L. \& Karsch, F.J. (1980) Pulsatile secretion of luteinizing hormone: differential suppression by ovarian steroids. Endocrinology 107, 1286-1290.

Goodman, R.L. \& Karsch, F.J. (1981) The hypothalamic pulse generator: a key determinant of reproductive cycles in sheep. In Biological Clocks in Seasonal Reproductive Cycles, pp. 223-236. Eds B. K. Follett \& D. E. Follett. Wright and Sons, Ltd, Bristol.

Karsch, F.J., Foster, D.L., Legan, S.J., Ryan, K.D. \& Peter, G.K. (1979) Control of the preovulatory endocrine events in the ewe. Inter-relationship of estradiol, progesterone and luteinizing hormone. Endocrinology 105, 421-426.

Karsch, F.J., Legan, S.J., Ryan, K.D. \& Foster, D.L. (1980) Importance of estradiol and progesterone in regulating $\mathrm{LH}$ secretion and estrous behaviour during the sheep estrous cycle. Biol. Reprod. 23, $404-413$.

Kesner, J.S., Convey, E.M. \& Anderson, C.R. (1981) Evidence that estradiol induces the pre-ovulatory LH surge in cattle by increasing pituitary sensitivity to $\mathrm{LHRH}$ and then increasing $\mathrm{LHRH}$ release. Endocrinology 108, 1386-1391.

Martin, G.B. (1984) Factors affecting the secretion of luteinizing hormone in the ewe. Biol. Rev. 59, 1-87.

McLeod, B.J. \& Haresign, W. (1984) Plasma LH concentrations in the ewe in response to repeated injections of low doses of gonadotrophin releasing hormone during the follicular phase of the oestrous cycle. $J$. Endocr. 101, 365-370.

McLeod, B.J., Haresign, W. \& Lamming, G.E. (1982) The induction of ovulation and luteal function in seasonally anoestrous ewes treated with small-dose multiple injections of GnRH. J. Reprod. Fert. 65, 215-221.

McLeod, B.J., Haresign, W. \& Lamming, G.E. (1983) Induction of ovulation in seasonally anoestrous ewes by continuous infusion of low doses of GnRH. $J$. Reprod. Fert. 68, 489-495.

McLeod, B.J., Peters, A.R., Haresign, W. \& Lamming, G.E. (1985) Plasma LH and FSH responses and ovarian activity in prepubertal heifers treated with repeated low doses of GnRH for $72 \mathrm{~h}$. J. Reprod. Fert. 74, 589-596.

McLeod, B.J., Haresign, W., Peters, A.R., Humke, R. \& Lamming, G.E. (1988) The development of subcutaneous-delivery preparations of GnRH for the induction of ovulation in acyclic sheep and cattle. Anim. Reprod. Sci. 17, 33-50.

Mori, Y. \& Kano, Y. (1984) Changes in plasma concentrations of $\mathrm{LH}$, progesterone and oestradiol in relation to the occurrence of luteolysis, oestrus and time of ovulation in the Shiba goat. J. Reprod. Fert. 72, 233-230.

Page, R.D., Keisler, D.H., Butcher, R.L., Dailey, R.A. \& Inskeep, E.K. (1987) Prepubertal and peripubertal changes in secretory patterns of LH and FSH in beef heifers. Anim. Reprod. Sci. 14, 85-93.

Peters, A.R. (1984) Effect of exogenous oestradiol-17 $\beta$ on gonadotrophin secretion in post-partum beef cows. J. Reprod. Fert. 72, 473-478.

Plotka, E.D., Seal, U.S., Verme, L.J. \& Ozoga, J.J. (1980) Reproductive steroids in deer. III. Luteinizing hormone, estradiol and progesterone around estrus. Biol. Reprod. 22, 576-581.

Rahe, C.H., Owens, R.E., Fleeger, J.L., Newton, H.J. \& Harms, P.G. (1980) Pattern of plasma luteinizing hormone in the cyclic cow: dependence upon the period of the cycle. Endocrinology 107, 498-503.

Schallenberger, E., Schams, D., Bulleman, B. \& Walters, D. (1984) Pulsatile secretion of gonadotrophins, ovarian steroids and ovarian oxytocin during prostaglandin-induced regression of the corpus luteum in the cow. J. Reprod. Fert. 71, 493-501.

Schams, D., Barth, D. \& Karg, H. (1980) LH, FSH and progesterone concentrations in peripheral plasma of the female roe deer (Capreolus capreolus) during the rutting season. J. Reprod. Fert. 60, 109-114.

Wallace, J.M \& McNeilly, A.S. (1985) Increase in ovulation rate after treatment of ewes with bovine follicular fluid in the luteal phase of the oestrous cycle. $J$. Reprod. Feri. 73, 505-515.

Wallace, J.M., Martin, G.D. \& McNeilly, A.S. (1988) Changes in the secretion of LH pulses, FSH and prolactin during the preovulatory phase of the oestrous cycle of the ewe and the influence of treatment with follicular fluid during the luteal phase. J. Endocr. 116, $123-135$.

Walters, D.L. \& Schallenberger, E. (1984) Pulsatile secretion of gonadotrophins, ovarian steroids and ovarian oxytocin during the periovulatory phase of the oestrous cycle in the cow. J. Reprod. Fert. 71, 503-512.

Walters, D.L., Schams, D. \& Schallenberger, E. (1984) Pulsatile secretion of gonadotrophins, ovarian steroids and ovarian oxytocin during the luteal phase of the oestrous cycle in the cow. J. Reprod. Fert. 71, $479-491$.

Wheeler, A.G., Baird, D.T., Land, R.B. \& Scaramuzzi, R.J. (1975) Increased secretion of progesterone from the ovary of the ewe during the pre-ovulatory period. J. Reprod. Fert. 45, 519-522.

Whisnant, C.S. \& Goodman, R.L. (1988) Effects of an opioid antagonist on pulsatile luteinizing hormone secretion in the ewe vary with changes in steroid negative feedback. Biol. Reprod. 39, 1032-1038.

Yuthasastrakosol, P., Palmer, W.M. \& Howland, B.E. (1977) Release of LH in anoestrous and cyclic ewes. J. Reprod. Fert. 50, 319-321.

Received 17 November 1989 